\title{
Integration of TTF, UTAUT, and ITM for mobile Banking Adoption
}

\section{Sayyed Khawar Abbas ${ }^{1}$, Hafiz Ali Hassan ${ }^{1}$, Jawad Asif ${ }^{2}$, Bilal Ahmed ${ }^{2}$, Fahad Hassan $^{1}$, Syed Salman Haider ${ }^{3}$}

\author{
${ }^{1}$ Hailey College of Commerce, University of the Punjab, Gujrat, Pakistan \\ ${ }^{2}$ Lecturer, Department of Commerce, University of Gujrat, Gujrat, Pakistan \\ ${ }^{3}$ Hailey College of Banking and Finance, University of the Punjab, Lahore, Pakistan
}

\begin{abstract}
The introduction of mobile banking facility has enabled customers to carry out banking transactionswith the use of smartphones and other handheld devices from anywhere. It has become a luxurious and exclusive method of online payments. The recent growth of telecommunication sector and a tremendous increase in mobile usage has opened new doors for sparking future of banking sector industry. The following research is aimed to find out the mobile banking adoption attitudes with the integration of TTF, UTAUT, and ITM models.

Keywords-TTF, ITM, UTAUT, Mobile banking, Adoption behaviour, Pakistan.
\end{abstract}

\section{INTRODUCTION}

The outraging technological advancements have made this world a global village. Most of the nations are interacting across borders for their common set of objectives (Hassan, Abbas, \& Zainab, 2018). In this scenario, the dependence on online sources for faster communication and liaison of multiple business features has become crucial and employee engagement based on services environment of an organization (Hassan et al., 2018). Therefore, the financial transactions are being carried out through online sources domestically and worldwide (Hong, Thong, Chasalow, \& Dhillon, 2011).

Mobile banking is the latest phenomenon in a series of mobile technology advancements. Although the availability of ATM (Automated Teller Machine), internet and telephone banking offers a variety of swift delivery service channels for traditional banking products, mobile banking is rapidly growing as a newest delivery source in developed and underdeveloped countries simultaneously (Safeena, Date, Kammani, \& Hundewale, 2012). The process of automation, simplification and task competency with the use of latest technology is a pivotal element for adoption behaviour in the modern era (Abbas S. K., Hassan, Asif, Junaid, \& Zainab, 2018). The extensive use of smartphones has impelled banks, software houses, microfinance institutions, and telecommunication service providers to design a new set of applications and products to extend client reach with the provision of more customised services with enhanced efficiency and reliability (Shaikh \& Karjaluoto, 2015). Similarly, the consumer credit market boosted its market share with the introduction of a variety of credit services through banks and other institutions (Abbas S. K., Hassan, Hashmi, \& Waqar, 2018).

Despite such benefits and task expectancy, the use of smartphones and personal digital assistants to conclude mobile banking transactions or to access financial information is relatively low as expected (Luarn \& Lin, 2005). According to Juniper Research (2013), it was proposed that approximately one billion people will be expected to use mobile banking by 2017 whereas, the level represents only $15 \%$ and half of the mobile users are nonbanking users. There are many reasons which are account for low tendency including various types of financial, credit, and other risks associated with online transactions. Furthermore, the low-income level is also responsible for, especially in underdeveloped nations (Abbas S. K., Hassan, Asif, \& Zainab, 2018). According to Abbas et al. (2018), the remodelling of risk management measures is crucial for banking sector performance. The introduction of more secure ways of online transactions and safeguard measures in case of uncertainty occurrence will help to get trust from potential consumers.

According to Afshan \& Sharif (2016), the telecommunication sector of Pakistan is growing multifold during the last decade. In the year 2014, Pakistan ranked $8^{\text {th }}$ for mobile usage all across the globe with more than 140 million users and 322, 683 million revenues (PTA, 2014). The outraging mobile usage has opened new market opportunities for banks and other financial institutions in the form of mobile banking concept as well as people are widely adopting this trend not 
only in developed but also in underdeveloped countries.(Ahmed, Ammar, \& ALI, 2016).

\section{LITERATURE REVIEW}

Mobile banking is known as SMS banking, electronic banking or agile banking(Vaidya, 2011). According to Zhou, $\mathrm{Lu}$, \& Wang (2010), mobile banking termed as phone banking is a mechanism in which banking customer can access his account information and perform online financial transactions with his internet-enabled smartphone or personal digital assistants (PDA's) by accessing bank's online server via wireless application protocol (WAP).

Shaikh \& Karjaluoto(2015), stated mobile banking was first introduced in 1990 by German company Paybox in collaboration with Deutsche Bank. At first, mobile banking was introduced and tested in European countries including Spain, Sweden, Germany, UK, and Austria. In developing countries, Kenya was the first one to introduce text-based mobile banking. Later on, it was dispersed all over the world. Several researchers have named mobile banking differently such as branchless banking (Ivatury \& Mas, 2008), mobile payments, m-transfers, m-finance,(Donner \& Tellez, 2008) and pocket banking (Safeena, Date, Kammani, \& Hundewale, 2012). Hence, Lee, \& Cheng(2007), argued mbanking is an application of mobile commerce where mobile consumers access their bank accounts through their smartphones. The mobile banking facility comes free from spatial constraints compared to Internet-based banking and consumers have the liberty to access their real-time accounts anywhere (Luo, Li, Zhang, \& Shim, 2010).

The concept of mobile banking is completely based on information technology structure. Information sharing effects broadly to employees working behaviour(Hassan, Asif, Waqar, Khalid, \& Abbas, 2018).Moreover, price, information and social context affect the consumption pattern(Hassan H. , Abbas, Zainab, Waqar, \& Hashmi, 2018) and Sharia screening process screening process also has some similarities with a country like Malaysia(Waris, Hassan, Abbas, Mohsin, \& Waqar, 2018) .It has seen that firms deficit normally emphasises on capital raising through equity in Pakistan(Asif, Abbas, \& Hassan, 2018), so, people considered more vigilant with their transaction day to day banking. Zhou, Lu, Wang (2010), explained mobile user adoption is based on various factors like a relative advantage, perceived usefulness, perceived ease of use, and technology acceptance. Junglas et al. (2008), explained advancement in technology might not lead to adoption if it is not fulfilling consumers' need, desire or perceptions. Whereas, people tend to follow technological advancements which are in line with their requirements and also improve their routine life (Goodhue \& Thompson, 1995).

The mobile banking usage research has enriched the information technology literature via business context not only in practical life but also in academic research field(Oliveira, Faria, Thomas, \& Popovič, 2014). Previously, various methods and techniques are being applied while exploring mobile banking adoption behaviors including TAM (technology acceptance model) presented by (Davis, 1989), IDT (innovation diffusion theory) by (Rogers, 1995), TTF (task-technology fit) from (Goodhue \& Thompson, 1995) and UTAUT (unified theory of acceptance and usage of technology) by (Venkatesh, Morris, Davis, \& Davis, 2003). Further, (Zhou, Lu, \& Wang, 2010) integrates TTF and UTAUT models for mobile banking adoption.

TTF model explains the acceptance of new technology is thoroughly dependent on its task fulfilment characteristics. Likewise, the technology must be failed if is not fulfilling the desired need or unable to improve routine life (Goodhue \& Thompson, 1995). The TTF model consists of four dimensions including task characteristics, task-technology, technology fit and use. The said model is widely used for research purposes like (Dishaw \& Strong, 1999), concluded research with the integration of TTF and TAM models. Similarly, Lee et al. (2007), modified TTF model while examining the mobile commerce adoption attitudes followed by (Zhou, Lu, \& Wang, 2010) completed their mobile banking behaviour research by assimilation TTF and UTAUT Models and (MHA, 2015)integrated TAM with perceived risks and benefits.

UTAUT is an extension of TAM model. The model not only explores the intention towards technological advancement but also examine subsequent behaviour. It includes three antecedents, effort expectancy, performance expectancy and social influence. The UTAUT model is bravely used for technology acceptance behaviours. Subsequently, (Oliveira, Faria, Thomas, \& Popovič, 2014 and Afshan \& Sharif, 2016) integrates task-technology fit, performance expectancy, technology characteristics, performance expectancy and initial trust model while exploring mobile banking adoption behaviours. The results of the studies above have explained these factors significantly impact the latest technology and mobile bankingadoption behaviours.

\section{METHODOLOGY}

Mobile banking is quite a new emerging technological fit for the upcoming banking system. It came with several pros and cons of the system. So, initially, this study utilises the questionnaire to collect the data. A questionnaire used by (Abbas S. , Hassan, Iftikhar, \& Waris, 2018) and (Oliveira, 
Faria, Thomas, \& Popovič, 2014) adopted for the study. The study uses the snowball sampling of the non-probability sampling technique. This study contains the setting of noncontrived and having minimal interference of researchers. Sampling frame contains larger cities of Pakistan which includes Islamabad, Karachi, Lahore, Gujranwala and Multan. Questionnaire distributed through email. Initially, 900 questionnaireswas distributed,but only 751 responses were complete. Following modelbeen studiedin this study.

$$
M B A=\alpha+\beta \text { TTF }+\beta U T A U T+\beta \text { ITM }+\varepsilon
$$

MBA $=$ Mobile Banking adoption

TTF $=$ Task-Technology Fit

UTAUT $=$ unified theory of acceptance and usage of technology
ITM= Initial Trust Model

Data collected from the questionnaire tested for its normality. Normality condition is fulfilled. Cronbach's Alpha was also around 0.70 for all of the constructs. So, reliability condition is also full filled. Data contains the 67\% male and 33\% females. Ages of the respondents were between 18 to 40 years. The majority were between 25 to 35 years and male.

\section{RESULTS}

Dependent variables were dichotomous, so binary logistic regression model is used for analysis. Following table represents the results.

\begin{tabular}{|c|c|c|c|}
\hline \multicolumn{4}{|c|}{ Variables in the equation } \\
\hline & B & S.E. & Sig. \\
\hline TTF & $.323 * *$ & .033 & .024 \\
\hline PE & $.103 * *$ & .011 & .045 \\
\hline $\mathrm{EE}$ & $.307 * *$ & .020 & .029 \\
\hline SI & $.133 * * *$ & .031 & .003 \\
\hline FC & $.210 * *$ & .091 & .021 \\
\hline IT & $.307 * *$ & .054 & .017 \\
\hline Constant & .233 & .235 & .129 \\
\hline
\end{tabular}

Above table shows the values of TTF (0.323) and IT (.307), it means both TTF and IT having strong positive relation with mobile baking adoption. Both are having significance at $5 \%$ level of significance. Whereas shaded area in the table shows the UTAUT components, an overall glance shows positive significance too. But delineate description shows PE (.103), EE (.307), FC (.210) having a strong positive relationship with mobile banking adoption at 5\% level of significance whereas, SI (.133) having a strong positive relationship at $1 \%$ level of significance. It shows that Social influence in Pakistan hasa significant role that other UTAUT components. Overall $\mathrm{R}$ square explains $67 \%$ to mobile banking adoption concerning TTF, UTAUT and ITM. Standard errors are less than beta,so data normality also confirmed here. Major parts of results are consistent with (Abbas S., Hassan, Iftikhar, \& Waris, 2018) and (Abbas S. K., Hassan, Asif, Junaid, \& Zainab, 2018). Whereas, rest of the results are consistent with (Oliveira, Faria, Thomas, \& Popovič, 2014).

\section{CONCLUSION}

Concluding the study results, it can be inferred that all three models TTF, UTAUT and ITM explains the mobile banking adoption in Pakistan UTAUT and ITM effects the intention to mobile banking adoption whereas TTF directly affects the mobile banking adoption. In the presentence of current results, it can understand that although UTAUT model is having stronger significance concerning Social influence the nature of significance and relation is same for both other models to mobile banking adoption. In Pakistan, Mobile banking adoption along with all other pros and cons are working and having scope to enhance its productivity. Technological aspect can be modified and can be a strong significant part later with the enhancement of technology. Whereas, Trust factor provides a very important role. Initially, people will trust mobile banking so that mobile banking can be enhanced. It could widen the base of mobile banking users in a very significant way. But Govt. and all other regularity authorises required to spread the mobile banking phenomenon through seminars and awareness schemes. So, their investment could get productivity level. This study is having the implications for regularity authorities, Mobile banking providers and Mobile banking users. Moreover, future researchers could develop a unique mechanism with timing, venality and political instability 
along with mobile banking adoption. It could show some

interesting results and findings for future research.

\section{REFERENCES}

[1] Abbas, S. K., Hassan, H. A., Asif, J., \& Zainab, F. (2018). HOW INCOME LEVEL DISTRIBUTION RESPONDS TO POVERTY: EMPIRICAL EVIDENCE FROM PAKISTAN. Global Scientific Journals, 6(3), 131-142.

[2] Abbas, S. K., Hassan, H. A., Asif, J., Junaid, H. M., \& Zainab, F. (2018). What are the key determinants of mobile banking Adoption in Pakistan? International Journal of Scientific \& Engineering Research, 9(2), 841-848.

[3] Abbas, S. K., Hassan, H. A., Hashmi, Z. M., \& Waqar, N. (2018). HOW COGNITIVE, EMOTIONAL AND BEHAVIORAL DETERMINANTS AFFECT CONSUMER CREDIT APPROACH? Global Scientific Journals, 6(3), 164-171.

[4] Abbas, S., Haider, S., Zainab, F., Hassan, H., \& Fazal, A. (2018). Why remodeling of risk management Practices in banking is required? Evidence from Pakistan. International Journal of Scientific \& Engineering Research, 9(2), 686-691.

[5] Abbas, S., Hassan, H., Iftikhar, S., \& Waris, A. (2018). Assimilation of TTF and UTAUT for Mobile Banking Usage . International Journal of Advanced Engineering, Management and Science , 4(4), 305-308.

[6] Afshan, S., \& Sharif, A. (2016). Acceptance of mobile banking framework in Pakistan. Telematics and Informatics, 33(2), 370-387.

[7] Ahmed, E. M., Ammar, A., \& ALI, A. E. (2016). SUDANESE MICROFINANCE SERVICES PROVIDERS DRIVERS FOR INTENTION TO ADOPT MOBILE BANKING. The Journal of Internet Banking and Commerce, 21(3), 1-12.

[8] Asif, J., Abbas, S., \& Hassan, H. (2018). Valuation Based Test of Market Timing Theory. International Journal of Academic Multidisciplinary Research , 2(4), 28-30.

[9] Davis, F. D. (1989). Perceived usefulness, perceived ease of use, and user acceptance of information technology. MIS quarterly, , 319-340.

[10] Dishaw, M. T., \& Strong, D. M. (1999). Extending the technology acceptance model with task-technology fit constructs. Information \& Management, 36(1), 9-21.

[11]Donner, J., \& Tellez, C. (2008). Mobile banking and economic development: linking, adoption, impact, and use. Asian J. Commun. , 18 (4), 318-332.
[12] Goodhue, D. L., \& Thompson, R. L. (1995). Tasktechnology fit and individual performance. MIS quarterly, 213-236.

[13] Hassan, H. A., Abbas, S. K., \& Zainab, F. (2018). ANATOMY OF TAKAFUL. Global Scientific Journals, 6(3), 143-155.

[14] Hassan, H., Abbas, S. K., Iftikhar, S., Waqar, N., \& Waris, A. (2018). Determinants Of Employee Engagement Practices In IT Sector. INTERNATIONAL JOURNAL OF SCIENTIFIC \& TECHNOLOGY RESEARCH, 7(5), 156-158.

[15] Hassan, H., Abbas, S., Zainab, F., Waqar, N., \& Hashmi, Z. (2018). Motivations for Green Consumption in an Emerging Market . Asian Journal of Multidisciplinary Studies, 6(5), 7-12.

[16] Hassan, H., Asif, J., Waqar, N., Khalid, S., \& Abbas, S. (2018). The Impact of Knowledge Sharing On Innovative Work Behavior . Asian Journal of Multidisciplinary Studies, 6(5), 22-25.

[17] Hong, W., Thong, J. Y., Chasalow, L. C., \& Dhillon, G. (2011). User acceptance of agile information systems: A model and empirical test. Journal of Management Information Systems, 28(1), 235-272.

[18] Ivatury, G., \& Mas, I. (2008). The early experience with branchless banking. . CGAP Focus Note, No. 46,.

[19] Junglas, I., Abraham, C., \& Watson, R. T. (2008). Tasktechnology fit for mobile locatable information systems. Decision Support Systems, 45(4), 1046-1057.

[20] Juniper Research. (2013). Mobile banking handset and tablet market strategies. Juniper Research.

[21]Lee, C. C., Cheng, H. K., \& vCheng, H. H. (2007). An empirical study of mobile commerce in insurance industry: Task-technology fit and individual differences. . Decision Support Systems, , 43(1), 95110.

[22]Luarn, P., \& Lin, H. H. (2005). Toward an understanding of the behavioral intention to use mobile banking. Computers in Human Behavior, 21(6), 873891.

[23]Luo, X., Li, H., Zhang, J., \& Shim, J. P. (2010). Examining multi-dimensional trust and multi-faceted risk in initial acceptance of emerging technologies: An empirical study of mobile banking services. . Decision support systems, , 49(2), 222-234.

[24] MHA, K. (2015). A mobile banking adoption model in the Jordanian market: an integration of TAM with perceived risks and perceived benefits. Journal of Internet Banking and Commerce, 20(3), 1.

[25] Oliveira, T., Faria, M., Thomas, M. A., \& Popovič, A. (2014). Extending the understanding of mobile banking 
adoption: When UTAUT meets TTF and ITM.

International Journal of Information Management, 34(5), 689-703.

[26]PTA. (2014). Pakistan Telecommunication Authority Govt Agency.

[27] Rogers. (1995). Diffusion of innovations (3 ed.). New York: New York Free Press.

[28] Safeena, R., Date, H., Kammani, A., \& Hundewale, N. (2012). Technology adoption and Indian consumers: study on mobile banking. International Journal of Computer Theory and Engineering, , 4(6), 1020.

[29] Shaikh, A. A., \& Karjaluoto, H. (2015). Mobile banking adoption: A literature review. . Telematics and Informatics, 32(1), 129-142.

[30] Vaidya, S. R. (2011). "Emerging Trends on Functional Utilization of Mobile Banking in Developed Markets in Next 3-4 Years". International Review of Business Research Papers , 7(1), 301 - 312.

[31] Venkatesh, V., Morris, M. G., Davis, G. B., \& Davis, F. D. (2003). User acceptance of information technology: Toward a unified view. . MIS quarterly, , 425-478.

[32] Waris, A., Hassan, H., Abbas, S., Mohsin, M., \& Waqar, N. (2018). Sharia Screening Process: A Comparison of Pakistan and Malaysia. Asian Journal of Multidisciplinary Studies, 6(5), 13-21.

[33]Zhou, T., Lu, Y., \& Wang, B. (2010). Integrating TTF and UTAUT to explain mobile banking user adoption. Computers in Human Behavior, 26(4), 760-767. 